\section{Efficacy of Microbial Amendments on Vegetables in Greenhouse and Field Trials}

\author{
Vincent M. Russo ${ }^{1}$ and Wayne W. Fish \\ U.S. Department of Agriculture, Agricultural Research Service, Wes Watkins \\ Agricultural Research Laboratory, 911 Highway 3W, Lane, OK 74555
}

Additional index words. bacteria, fungi, organic, protected culture

\begin{abstract}
Possible effects of microbe-containing amendments on vegetable development need clarification. Eight-week-old, organically grown seedlings of a bell, cv. Jupiter, and a non-pungent jalapeño, cv. Pace 105, pepper, both $C$. annuum $\mathrm{L}$., were transplanted into pots containing an organic potting medium in a greenhouse experiments repeated over 2 years. Pots were fertilized with Neptune's Harvest ${ }^{\circledR}$, a fish emulsion. One of eight amendments [Actinovate AG $₫$, Bio Inoculant ${ }^{\circledR}$, Bio-S.I. $₫$, Compost Tea ${ }^{\circledR}$ (a decoction of biological material), Mpact ${ }^{\circledR}$, 'PMSLA and EO-12' ${ }^{\circledR}$, Soil Activator ${ }^{\circledR}$, Super Bio $\left.{ }^{\circledR}\right]$ was applied at label rates and application timings. The control was Neptune's Harvest only. Three plants from each treatment were periodically harvested. Heights and total fresh and dry weights were determined. At a single terminal harvest, numbers and weights and chlorophyll, carotenoids, and vitamin $C$ contents of fruit were determined. At the conclusion of the study the control, Bio-S.I., Compost Tea, PMSLA and EO-12, and Soil Activator generally produced bell pepper plants that were taller and heavier than those produced by Actinovate AG, Bio Inoculant, Mpact, and Super Bio. Numbers and weights of bell pepper fruit were not consistent over amendments or years. Heights for cv. Pace 105 plants treated with Compost Tea were similar to the control and taller than all others. Plant fresh weights for the control and Compost Tea were similar to that for Bio-S.I. and greater than all others. Dry weight, number and fresh weight of fruit and levels of chlorophylls, carotenoids, and vitamin $\mathrm{C}$ in fruit were unaffected. Compost Tea, PMSLA, and Soil Activator were tested in field trials in 2010 and 2011 using both peppers, cucumber (Cucumis sativus L.), cv. Earli Pik, and sweet corn (Zea mays var. rugosa Bonaf), cv. Incredible. Amendments provided no particular benefits under greenhouse or field conditions.
\end{abstract}

Plants roots interact with microbes in beneficial and detrimental ways (Sylvia et al., 1997; Thies and Grossman, 2006). Soil biotas are involved in mineralization of nutrients to be taken up by plants with mineralization efficiency, in part dictated by the microorganism population (Prosser, 2006). Generally there is a balance between beneficial and plant pathogenic microorganisms (Van Elsas et al., 2006). Detrimental microorganisms can be suppressed as a result of competition, parasitism/predation, induced resistance, or antibiosis (Al-Rawahi and Hancock, 1998;

Received for publication 6 Dec. 2011. Accepted for publication 6 Feb. 2012

Mention of a trademark, vendor, or proprietary product does not constitute a guarantee or warranty of the product by the U.S. Department of Agriculture (USDA) and does not imply its approval to the exclusion of other products that may be suitable. USDA employees prepared the article as part of their official duties. Copyright protection under U.S. copyright law is not available for such works, and there is no copyright to transfer. The fact that the private publication in which the article appears is itself copyrighted does not affect the material that is a work product of the U.S. government, which can be freely reproduced by the public. The USDA is an equal opportunity employer.

${ }^{1}$ To whom reprint requests should be addressed; e-mail vincent.russo@ars.usda.gov.
De Cal et al., 2000; Metcalf et al., 2004; Thomashow and Weller, 1996; Zaki et al., 1998). Mixes of microorganisms may provide a greater range of protection than a single organism (Michaud et al., 2002).

Rhizosphere bacteria can benefit plant development (Glick, 2004; Kokalis-Burelle et al., 2003; Lucy et al., 2004; Russo, 2006; Schulze and Pöschel, 2004; Shimshick and Herbert, 1979; Zahir et al., 2004; Zehnder et al., 2001). Rhizobia bacteria may interact with mycorrhizal fungi to increase root colonization and increase nutrient content in plants (Gravel et al., 2009; Singh and Adholeya, 2002; Suresh and Bagyaraj, 2002). Russo and Perkins-Veazie (2010) found that when bell pepper (Capsicum annuum L.) was sown into a medium inoculated with mixes of bacteria in the greenhouse, there was little effect on plant development after seedlings were subsequently transplanted to the field.

Peppers are grown in temperate to tropical climates in various soil types and are diverse in plant size and in fruit size and shape. The role of microbes in pepper production needs clarification (Douds and Reider, 2003; Nemec et al., 1996; Russo, 2006). However, it is accepted that plants grown in the field without a diverse soil microbial population would not develop and produce at acceptable levels.
Several microorganism-containing commercial products claim various benefits for plants. It is necessary to assess these products so producers have information to determine whether use of the products is justified. Growing plants under greenhouse conditions allows screening of materials under controlled conditions with results on how cultivars react to various treatments. The project was undertaken to screen soil amendments for effects on growth, development, and some phytonutrient contents of peppers.

\section{Materials and Methods}

Greenhouse culture. Experiments were conducted in a greenhouse at Lane, OK. Seedlings were produced for later transfer to pots using the methods of Russo (2006). New Speedling ${ }^{\circledR}$ planting trays (American Plant Products, Oklahoma City, OK), $72.5 \times$ $34.5 \times 6.2 \mathrm{~cm}($ length $\times$ width $\times$ depth $), 128$ cells per tray, were used. Cell dimensions were $3.7 \times 3.7 \mathrm{~cm}$ (length $\times$ width) with each cell having a volume of $36 \mathrm{~cm}^{3}$. New plastic inserts (American Plant Products; $3.5 \times 3.5 \times 6 \mathrm{~cm}$, length $\times$ width $\times$ depth, volume $30 \mathrm{~cm}^{3}$ ) were placed in planting tray cells.

The potting medium Sunshine LC1 [SunGro, Bellevue, WA; Organic Materials Review Institute (OMRI)-listed, Eugene, OR] was used. Major components of the medium are sphagnum, perlite, peatmoss, gypsum, and dolomitic limestone. Before filling trays, the medium from all bags were combined, moistened, and mixed so that plants received potting mix of similar nutrient content. After placement in trays, the medium was again moistened with potable tap water. Bell pepper, cv. Jupiter (Twilley, Hodges, SC), and a non-pungent jalapeño pepper, cv. Pace 105 (C. annuum; Campbell Seed, Davis, CA), were used to screen amendments in the greenhouse for use in field trials. Seed of the cultivars were not available from an organic source; untreated seed were used in accordance with National Organic Program guidelines [United States Department of Agriculture/ Agricultural Marketing Service (USDA, AMS), 2000]. Three seed of each species were sown in each cell on 26 July 2009 and 28 Sept. 2010. Trays were placed on 1-m high perforated metal benches.

Trays, and emerged plants, were misted at $0900 \mathrm{HR}$ and 1500 and 1800 HR daily through three emitters/bench for $2 \mathrm{~min} /$ application with each emitter delivering $\approx 850 \mathrm{~mL} \cdot \mathrm{min}^{-1}$ $\left(5.1 \mathrm{~L} \cdot \mathrm{d}^{-1}\right)$. The irrigation water and potting medium contributed nutrients to plants (Tables 1 and 2). Greenhouse temperatures averaged $33 / 22 \pm 1{ }^{\circ} \mathrm{C}$ (day/night). Fluorescent light, 430 lumens $/ \mathrm{m}^{3}$ (Sun Agro; Phillips, Sommerset, NJ), was used to provide plants with a minimum of $12 \mathrm{~h}$ of a mix of sunlight and artificial light.

Two weeks after sowing, when emergence was $90 \%+$, plants were thinned to one/cell. Weekly fertilization with Neptune's Harvest ${ }^{\circledR}$ (Ocean Crest Seafoods, Gloucester, ME; OMRI-listed; nutrient content, Table 2), a mix of fish products and seaweed, was begun when 
Table 1. Values for constituents ${ }^{\mathrm{z}}$ of the irrigation water used in the greenhouse.

\begin{tabular}{|c|c|c|c|c|c|c|c|c|c|c|c|}
\hline \multirow[b]{2}{*}{$\mathrm{pH}$} & \multicolumn{9}{|c|}{$\left(\mu g \cdot g^{-1}\right)$} & \multirow[b]{2}{*}{ Hardness } & \multirow[b]{2}{*}{$\mathrm{EC}\left(\mu \mathrm{mhom} \cdot \mathrm{cm}^{-1}\right)$} \\
\hline & $\mathrm{NO}_{3}-\mathrm{N}$ & Potassium & Boron & Calcium & Chloride & Sodium & $\mathrm{CaCO}_{3}$ & Magnesium & $\overline{\mathrm{SO}_{4}}$ & & \\
\hline 9.5 & $<1$ & 2 & 0.07 & 13 & 15 & 16 & 41 & 2 & 12 & 39 & 151 \\
\hline
\end{tabular}

${ }^{\mathrm{z} A n a l y s e s ~ p e r f o r m e d ~ b y ~ t h e ~ O k l a h o m a ~ S t a t e ~ U n i v e r s i t y ~ S o i l, ~ W a t e r ~ \& ~ F o r a g e ~ A n a l y t i c a l ~ L a b o r a t o r y, ~ S t i l l w a t e r, ~ O K . ~}$

$\mathrm{EC}=$ electrical conductivity.

Table 2. Values for constituents ${ }^{z}$ of the Sunshine potting medium and the Neptune's Harvest fertilizer diluted in the irrigation water.

\begin{tabular}{|c|c|c|c|c|c|c|c|c|c|c|c|c|c|c|}
\hline \multirow[b]{2}{*}{ Source } & \multirow[b]{2}{*}{$\mathrm{pH}$} & \multicolumn{12}{|c|}{$\left(\mu g \cdot g^{-1}\right)$} & \multirow[b]{2}{*}{$\mathrm{EC}\left(\mu \mathrm{mhom} \cdot \mathrm{cm}^{-1}\right)$} \\
\hline & & $\overline{\mathrm{NH}_{3}}$ & $\mathrm{NO}_{3}-\mathrm{N}$ & Phosphorus & Potassium & Boron & Calcium & Copper & Iron & Sodium & Magnesium & $\mathrm{SO}_{4}$ & $\overline{\text { Zinc }}$ & \\
\hline Potting medium & 7.0 & 69.7 & 85.0 & 8.4 & 22.0 & 0.1 & 100 & 1 & 14.5 & 29 & 59 & 90 & 1.2 & 1425 \\
\hline Neptune's Harvest & $5.4^{\mathrm{y}}$ & 22.8 & 35.6 & 4.0 & 388.0 & 100 & 0.4 & 120 & $-^{\mathrm{x}}$ & 316 & 12 & 84 & - & 2628 \\
\hline
\end{tabular}

${ }^{\mathrm{z}}$ Analyses performed by the Oklahoma State University Soil, Water \& Forage Analytical Laboratory, Stillwater, OK.

${ }^{\mathrm{y}} \mathrm{pH}$ value is for diluted solution of Nature's Harvest used for fertilization.

$\mathrm{x}$

$\mathrm{EC}=$ electrical conductivity.

Table 3. Frequency and date of application of amendments used in the greenhouse from Sept. 2009 to Jan. 2010 and Dec. 2010 to Mar. 2011.

\begin{tabular}{|c|c|c|c|c|c|c|c|c|c|c|c|c|}
\hline \multirow[b]{2}{*}{ Amendment $^{\mathrm{z}, \mathrm{y}}\left(\mathrm{mL} \cdot \mathrm{L}^{-1}\right)$} & \multicolumn{12}{|c|}{ Day of application after seedlings transplanted to pots } \\
\hline & 0 & 14 & 28 & 35 & 42 & 49 & 56 & 63 & 70 & 84 & 98 & $112^{x}$ \\
\hline Actinovate AG (7.5) & $\mathrm{X}$ & & $\mathrm{X}$ & & & $\mathrm{X}$ & & & $\mathrm{X}$ & & $\mathrm{X}$ & $\mathrm{X}$ \\
\hline Bio Inoculant (7.5) & $\mathrm{X}$ & & & & & & & & & & & \\
\hline Bio-S.I. (0.04) & $\mathrm{X}$ & $\mathrm{X}$ & $\mathrm{X}$ & & $\mathrm{X}$ & & $\mathrm{X}$ & & $\mathrm{X}$ & $\mathrm{X}$ & $\mathrm{X}$ & $\mathrm{X}$ \\
\hline Compost Tea (52.5) & $\mathrm{X}$ & & & & & & & & & & & \\
\hline Mpact (7.5) & $\mathrm{X}$ & & & $\mathrm{X}$ & & & & $\mathrm{X}$ & & & $\mathrm{X}$ & $\mathrm{X}$ \\
\hline PMSLA and EO-12 (7.5) & $\mathrm{X}$ & & & & & & & & & & & \\
\hline Soil Activator (7.5) & $\mathrm{X}$ & & & & & & & & & & & \\
\hline Super Bio (7.5) & $\mathrm{X}$ & & & & & & $\mathrm{X}$ & & & & $\mathrm{X}$ & $\mathrm{X}$ \\
\hline
\end{tabular}

${ }^{z}$ All plants provided Neptune's Harvest ${ }^{\circledR}$ (Ocean Crest Seafoods, Gloucester, ME; OMRI-listed) weekly with 30 mL·L ${ }^{-1}$; the control received Neptune's Harvest ${ }^{\circledR}$ weekly and no other amendment.

${ }^{\mathrm{y}}$ Material and supplier: Actinovate $\mathrm{AG}{ }^{\circledR}=$ Natural Industries, Inc., Houston, TX; Bio-inoculant Plus Humus ${ }^{\circledR}=$ Bio Inoculant Inc., Sanger, TX; Bio-S.I. ${ }^{\circledR}=$ BioS.I. Technology, LLC, Argyle, TX; Compost Tea = Erath Earth Inc., Hico, TX; Mpact = Enviro Products Corporation, Broken Arrow, OK; PMSLA and EO-12 $®=$ Earthwise Organics, Harlingen, TX; Soil Activator and Beneficial Microbes ${ }^{\circledR}=$ Medina Agricultural Products Co., Inc., West, Hondo, TX 78861; and Super Bio ${ }^{\circledR}=$ Advanced Microbial Solutions, Pilot Point, TX 76258. Combinations and concentrations of microbes in amendments are proprietary.

${ }^{\mathrm{x}}$ Application time only used in the Sept. 2009 to Jan. 2010 timeframe in the greenhouse.

Table 4. Values for constituents ${ }^{\mathrm{z}}$ of the chicken litter delivered and before application to soil.

\begin{tabular}{|c|c|c|c|c|c|c|c|c|c|c|c|c|c|}
\hline \multirow[b]{2}{*}{$\mathrm{pH}$} & \multicolumn{8}{|c|}{$(\%)$} & \multicolumn{4}{|c|}{$\left(\mu g \cdot g^{-1}\right)$} & \multirow[b]{2}{*}{$\mathrm{EC}\left(\mu \mathrm{mho} \cdot \mathrm{cm}^{-1}\right)$} \\
\hline & Carbon & Nitrogen & $\mathrm{P}_{2} \mathrm{O}_{5}$ & $\mathrm{~K}_{2} \mathrm{O}$ & Calcium & Magnesium & Sodium & Sulfur & Copper & Iron & Manganese & $\overline{\text { Zinc }}$ & \\
\hline 7.85 & 26.8 & 1.8 & 2.7 & 2.6 & 2.4 & 0.6 & 0.7 & 0.9 & 517 & 573 & 447 & 375 & 12,460 \\
\hline
\end{tabular}

${ }^{\mathrm{z}}$ Analyses performed by the Oklahoma State University Soil, Water \& Forage Analytical Laboratory, Stillwater, OK.

$\mathrm{EC}=$ electrical conductivity.

Table 5. Results of analysis of variance for growth and yield characteristics in greenhouse grown bell and non-pungent Jalapeño peppers.

\begin{tabular}{|c|c|c|c|c|c|c|c|c|c|c|}
\hline \multirow[b]{3}{*}{ Source } & \multicolumn{6}{|c|}{ Plant } & \multicolumn{4}{|c|}{ Fruit } \\
\hline & $\mathrm{Ht}$ & Fresh wt & Dry wt & $\mathrm{Ht}$ & Fresh wt & Dry wt & Number & Fresh wt & Number & Fresh wt \\
\hline & $\overline{2009-2010}$ & $\overline{2009-2010}$ & $\overline{2009-2010}$ & $\overline{2010-2011}$ & $\overline{2010-2011}$ & $\overline{2010-2011}$ & $\overline{2009-2010}$ & $\overline{2009-2010}$ & $\overline{2010-2011}$ & $\overline{2010-2011}$ \\
\hline & \multicolumn{10}{|c|}{ Bell pepper } \\
\hline Amendment (A) & $* *$ & $* *$ & $* *$ & $* *$ & $* *$ & $* *$ & $*$ & $* *$ & $*$ & $* *$ \\
\hline Sampling date (D) & $* *$ & $* *$ & $* *$ & $* *$ & $* *$ & $* *$ & $\underline{z}^{\mathrm{z}}$ & - & - & - \\
\hline \multicolumn{11}{|l|}{ Interaction } \\
\hline \multirow[t]{2}{*}{$\mathrm{A} \times \mathrm{D}$} & $* *$ & $* *$ & $* *$ & $* *$ & $* *$ & $* *$ & - & - & - & - \\
\hline & \multicolumn{10}{|c|}{ Non-pungent jalapeño } \\
\hline Amendment (A) & $* *$ & $* *$ & NS & $* *$ & $* *$ & NS & NS & NS & NS & NS \\
\hline Sampling date (D) & $* *$ & $* *$ & $* *$ & $* *$ & $* *$ & $* *$ & - & - & - & - \\
\hline Interaction & & & & & & & & & & \\
\hline $\mathrm{A} \times \mathrm{D}$ & NS & NS & NS & $* *$ & $* *$ & NS & - & - & - & - \\
\hline
\end{tabular}

$z_{-}=$analyses associated with fruit were only at harvest; bell pepper in Jan. 2010 and Mar. 2011; non-pungent Jalapeño in Jan. 2010 and Mar. 2011.

NS, *,*Nonsignificant or significant at $P \leq 0.05$ or $P \leq 0.01$, analysis of variance.

first true leaves emerged. Before fertilizations, the Neptune's Harvest container was shaken to ensure contents were mixed. The fertilizer was mixed at $30 \mathrm{~mL} \cdot \mathrm{L}^{-1}$ (Russo, 2006) and
$500 \mathrm{~mL}$ applied to each tray. Unused material was kept in the closed container.

On 11 Sept. 2009 and 12 Nov. 2010, individual seedlings were transferred to new, moistened Sunshine Potting mix in 4-L pots, which received one of eight amendments (Table 3) applied as recommended by manufacturers with treatment beginning on these 

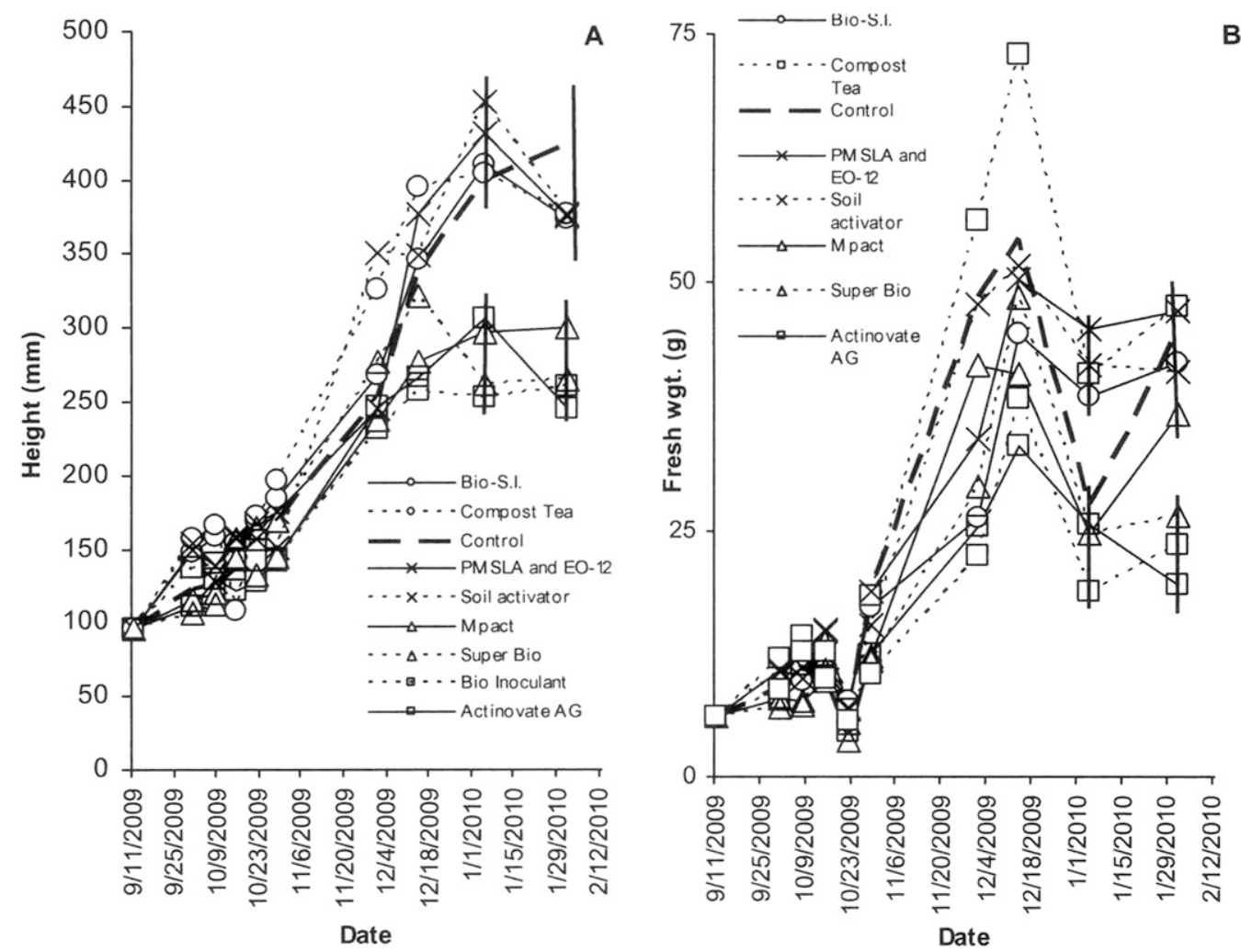

B



Fig. 1. Effects of amendment over sampling time on plant $(\mathbf{A})$ height, $(\mathbf{B})$ fresh weight, and $(\mathbf{C})$ dry weight in bell pepper. SE bars are provided at apparent points of separation and/or at the final sampling date in Jan. 2010. The control is Nature's Harvest supplied weekly at $30 \mathrm{~mL} \cdot \mathrm{L}^{-1}$.

dates. Microbial contents and concentrations are proprietary but materials are generally comprised of beneficial bacteria and/or fungi or decoctions of composts or manures in water. At establishment in pots, and weekly thereafter, plants were supplied with 100
mL of Neptune's Harvest fertilizer solution at the rate described previously. Controls were plants treated only with Neptune's Harvest. At various times, three plants from each cultivar $\times$ amendment combination, and the control, were removed from pots and height from the root collar to the terminal bud measured. Bell pepper sampling dates in 2009-2010 were: 11 Sept. 2009; 1, 8, 15, 22, and 29 Oct. 2009; 4 and 14 Dec. 2009; 2 and 28 Jan. 2010. Sampling dates in 2010-2011 were: 13 Dec. 2010; 3, 13, and 
29 Jan. 2011; 14 Feb. 2011; and 7 and 16 Mar. 2011. Non-pungent jalapeño pepper sampling dates in 2009-2010 were: 1, 8, 15, 22, and 29 Oct. 2009; 4 and 14 Dec. 2009; and 2 and 28 Jan. 2010. Sampling dates in 2010-2011 were: 13 Dec. 2010; 3, 13, and 29 Jan. 2011; 14 Feb. 2011; and 7 and 16 Mar. 2011. Sampling dates included vegetative and reproductive stages of plants. Potting mix adhering to roots of plants was gently removed in water; plants were blot-dried, and fresh weights of entire plants determined. Plants were placed individually in paper bags and into a hot air convection oven for drying at $66{ }^{\circ} \mathrm{C}$ for up to 1 week. At final harvests, 28 Jan. 2010 or 16 Mar. 2011, for both pepper types marketable-sized fruit for each type were removed from plants, counted, and weighed separate from the plant biomass. Fruit that were not of marketable size were left on plants and included in the total plant biomass weight.

Chlorophyll and carotenoids were extracted from fruit at harvest and quantified with an ultraviolet-VIS spectrophotometer (ultraviolet2450; Shimadzu, Kyoto, Japan) using methods of Lichtenhaler and Buschmann (2001). Chlorophyll $a$, chlorophyll $b$, and carotenoids were measured at wavelengths of 664 , 647 , and $470 \mathrm{~nm}$, respectively. Total vitamin $\mathrm{C}$ was determined with methods of Hodges et al. (2001) with readings at $525 \mathrm{~nm}$. Measurements were compared with appropriate standards.

Field culture. Tests were conducted in a Bernow, fine loamy, thermic, glossic, Paleudalf soil, which averaged $\mathrm{pH} 6.5$ and nitrogen:phosphorus:potassium levels of 6:80:180 $\mathrm{kg} \cdot \mathrm{ha}^{-1}$. The overwinter wheat (Triticum aestivum L.) cover was mowed and incorporated. Before bed formation, $2.2 \mathrm{Mt} \cdot \mathrm{ha}^{-1}$ of composted chicken litter (nutrient content, Table 4), the maximum amount allowed by the state of Oklahoma for a single-year application, was broadcast-applied and incorporated. The soil was formed into 4.6-m long beds on 0.9 -m centers. Six-week-old transplants of bell and non-pungent jalapeño peppers were grown in the 128 cell trays as described previously. Ten seedlings were transplanted in single rows in the middle of beds with plants spaced at $0.45 \mathrm{~m}$ in rows. Seed of cucumber (Cucumis sativus L.), cv. Earli Pik, and sweet corn (Zea mays var. rugosa Bonaf.), cv. Incredible, were sown in single rows in the middle of beds on $14 \mathrm{Apr}$. 2010. Cucumber was spaced $0.45 \mathrm{~m}$ between plants and sweet corn spaced $11.5 \mathrm{~cm}$ between plants. In 2011, an initial planting was established on $15 \mathrm{Apr}$.; as a result of unseasonal hot, dry weather during the spring and early summer, only cucumber and the non-pungent jalapeño peppers were able to be harvested in the normal harvest window. Bell pepper was re-established from seedlings produced as described previously on 10 Aug. All plants were established in four bed blocks with data obtained from the center two beds. Treatments included: the control (chicken litter only); Compost Tea; PMSLA and EO-12, and Soil Activator applied according to manufacturer directions. In 2010, yields for crops were determined. In 2011, yields of all but sweet corn were determined. In 2011, sweet corn stalks from 2 linear meters of row were cut at the ground line and stalk fresh weight determined.

Statistical analyses. Experimental designs for the greenhouse and field were randomized complete blocks. There were three replications of each treatment for each crop. Data were subjected to analysis of variance in SAS (SAS Inc., Cary, NC). If significant interactions were present, they were used to explain results; if not, the Ryan-Einot-GabrielleWelsch multiple F test in SAS was used to separate main effects.

\section{Results}

Greenhouse. As a result of differences in date of trial initiation and lengths of time over which samples were taken, results from trials were considered separately. Cultivars were not compared directly as a result of differences in habit and fruit size.

Plant development, 2009-2010 trial. Amendment, sampling date, and the interaction affected plant height and plant fresh and dry weights; amendment affected fruit number and fresh weights of bell pepper (Table 5). Through mid-Dec. 2009, there was little

Table 6. Effect of amendment on number and fresh weight of bell pepper fruit and height and fresh weight of non-pungent Jalapeño plants in the greenhouse.

\begin{tabular}{|c|c|c|c|c|c|c|}
\hline \multirow[b]{4}{*}{ Amendment } & \multicolumn{4}{|c|}{ Fruit } & \multicolumn{2}{|c|}{ Plant } \\
\hline & Number & Fresh wt (g) & Number & Fresh wt (g) & $\mathrm{Ht}(\mathrm{mm})$ & Fresh wt $(\mathrm{g})$ \\
\hline & $\overline{2009-2010}$ & $\overline{2009-2010}$ & $\overline{2010-2011}$ & $2010-2011$ & $\overline{2009-2010}$ & $\overline{2009-2010}$ \\
\hline & & & & & Non-pung & nt jalapeño \\
\hline$\overline{\text { Control }^{z}}$ & $1.3 \mathrm{~b}$ & $119.8 \mathrm{a}$ & $1.6 \mathrm{ab}$ & $73.4 \mathrm{~b}$ & $221.6 \mathrm{ab}^{\mathrm{y}}$ & $20.4 \mathrm{a}$ \\
\hline Compost Tea & $2.0 \mathrm{ab}$ & $112.7 \mathrm{ab}$ & $2.8 \mathrm{a}$ & $150.7 \mathrm{a}$ & $240.1 \mathrm{a}$ & $21.7 \mathrm{a}$ \\
\hline Bio-S.I. & $2.7 \mathrm{a}$ & $102.8 \mathrm{abc}$ & $2.0 \mathrm{ab}$ & $96.5 \mathrm{~b}$ & $212.3 \mathrm{bc}$ & $18.3 \mathrm{ab}$ \\
\hline PMSLA and EO-12 & $2.0 \mathrm{ab}$ & $97.7 \mathrm{abc}$ & $1.8 \mathrm{ab}$ & $99.6 \mathrm{~b}$ & $210.5 \mathrm{bc}$ & $16.5 \mathrm{bc}$ \\
\hline Actinovate AG & $1.7 \mathrm{ab}$ & $68.3 \mathrm{c}$ & $1.8 \mathrm{ab}$ & $93.2 \mathrm{~b}$ & $210.2 \mathrm{bc}$ & $14.7 \mathrm{bc}$ \\
\hline Super Bio & $2.0 \mathrm{ab}$ & $93.0 \mathrm{abc}$ & $1.2 \mathrm{ab}$ & $69.1 \mathrm{~b}$ & $204.0 \mathrm{bc}$ & $15.5 \mathrm{bc}$ \\
\hline Soil Activator & $1.7 \mathrm{ab}$ & $112.0 \mathrm{abc}$ & $1.6 \mathrm{ab}$ & $104.9 \mathrm{~b}$ & $201.5 \mathrm{bc}$ & $15.8 \mathrm{bc}$ \\
\hline Mpact & $1.0 \mathrm{~b}$ & $73.8 \mathrm{bc}$ & $1.2 \mathrm{~b}$ & $68.4 \mathrm{~b}$ & $196.2 \mathrm{bc}$ & $16.0 \mathrm{bc}$ \\
\hline Bio Inoculant & $1.3 \mathrm{~b}$ & $86.8 \mathrm{abc}$ & $1.2 \mathrm{~b}$ & $72.7 \mathrm{~b}$ & $189.8 \mathrm{c}$ & $13.2 \mathrm{c}$ \\
\hline
\end{tabular}

${ }^{z}$ Control is Nature's Harvest supplied weekly at $30 \mathrm{~mL} \cdot \mathrm{L}^{-1}$.

${ }^{y}$ Values in a column followed by the same letter are not significantly different, $P \leq 0.05$, Ryan-EinotGabriel-Welsch multiple F test.

Table 7. Effect of sampling date on plant height and fresh and dry weights of non-pungent Jalapeño plants in the greenhouse, 2009-2010.

\begin{tabular}{|c|c|c|c|c|}
\hline \multirow[b]{3}{*}{ Sampling date } & \multicolumn{4}{|c|}{ Plant } \\
\hline & $\mathrm{Ht}(\mathrm{mm})$ & Fresh wt (g) & Dry wt (g) & Dry wt $(\mathrm{g})$ \\
\hline & \multicolumn{2}{|c|}{$2009-2010$} & \multicolumn{2}{|c|}{$2010-2011$} \\
\hline$\overline{1^{z}}$ & $156.9 \mathrm{c}$ & $8.8 \mathrm{e}$ & $1.1 \mathrm{~d}$ & $0.3 \mathrm{e}$ \\
\hline 2 & $152.3 \mathrm{c}$ & $9.6 \mathrm{e}$ & $1.5 \mathrm{c}$ & $1.1 \mathrm{~d}$ \\
\hline 3 & $162.6 \mathrm{c}$ & $10.0 \mathrm{e}$ & $1.6 \mathrm{~cd}$ & $3.1 \mathrm{~b}$ \\
\hline 4 & $159.1 \mathrm{c}$ & $6.7 \mathrm{e}$ & $1.1 \mathrm{~d}$ & $1.8 \mathrm{c}$ \\
\hline 5 & $168.5 \mathrm{c}$ & $16.3 \mathrm{~d}$ & $2.2 \mathrm{bc}$ & $2.5 \mathrm{~b}$ \\
\hline 6 & $249.1 \mathrm{~b}$ & $26.1 \mathrm{~b}$ & $4.8 \mathrm{a}$ & $3.1 \mathrm{~b}$ \\
\hline 7 & $283.3 \mathrm{a}$ & $33.7 \mathrm{a}$ & $4.4 \mathrm{a}$ & $3.7 \mathrm{a}$ \\
\hline 8 & $288.3 \mathrm{a}$ & $19.6 \mathrm{~cd}$ & $2.6 \mathrm{~b}$ & $-\mathrm{y}$ \\
\hline 9 & $266.0 \mathrm{ab}$ & $21.4 \mathrm{c}$ & $2.8 \mathrm{~b}$ & - \\
\hline
\end{tabular}

In 2009-2010, sampling dates were $1=1$ Oct. $2009,2=8$ Oct. $2009,3=15$ Oct. $2009,4=22$ Oct. 2009 $5=29$ Oct. $2009,6=4$ Dec. $2009,7=14$ Dec. $2009,8=2$ Jan. $2010,9=28$ Jan. 2010; in 2010-2011, sampling dates were $1=13$ Dec. 2010, $2=3$ Jan. 2011, $3=13$ Jan. 2011, $4=29$ Jan. 2011, $5=14$ Feb. 2011, $6=7$ Mar. 2011, and $7=16$ Mar. 2011 .

$y_{-}=$not measured on dates after 16 Mar. 2011 for the 2010-2011 trial. 
numbers of fruit (average 2.1/plant), and fruit fresh weight (average $51.3 \mathrm{~g}$ ) were unaffected by amendment (Table 5). Control plants were taller than those in most other treatments except for those treated with Compost Tea, which were similar (Table 6). Compost Tea-treated plants and controls had the greatest plant fresh weights
(Table 6). Plant heights increased throughout (Table 7). Plant fresh and dry weights increased through the sixth and seventh sampling dates and then decreased (Table 7).

Plant development, 2010-2011 trial. Amendment, sampling date, and the interaction affected plant height and bell pepper plant fresh and dry weights; amendment affected fruit number and fresh weights (Table 5). At the last sampling plants, treated with Compost Tea, Bio-inoculant, and PMSLA and EO12 were taller than those grown with any other treatment or the control; plants treated with Bio-S.I. were shortest (Fig. 2A). At the last
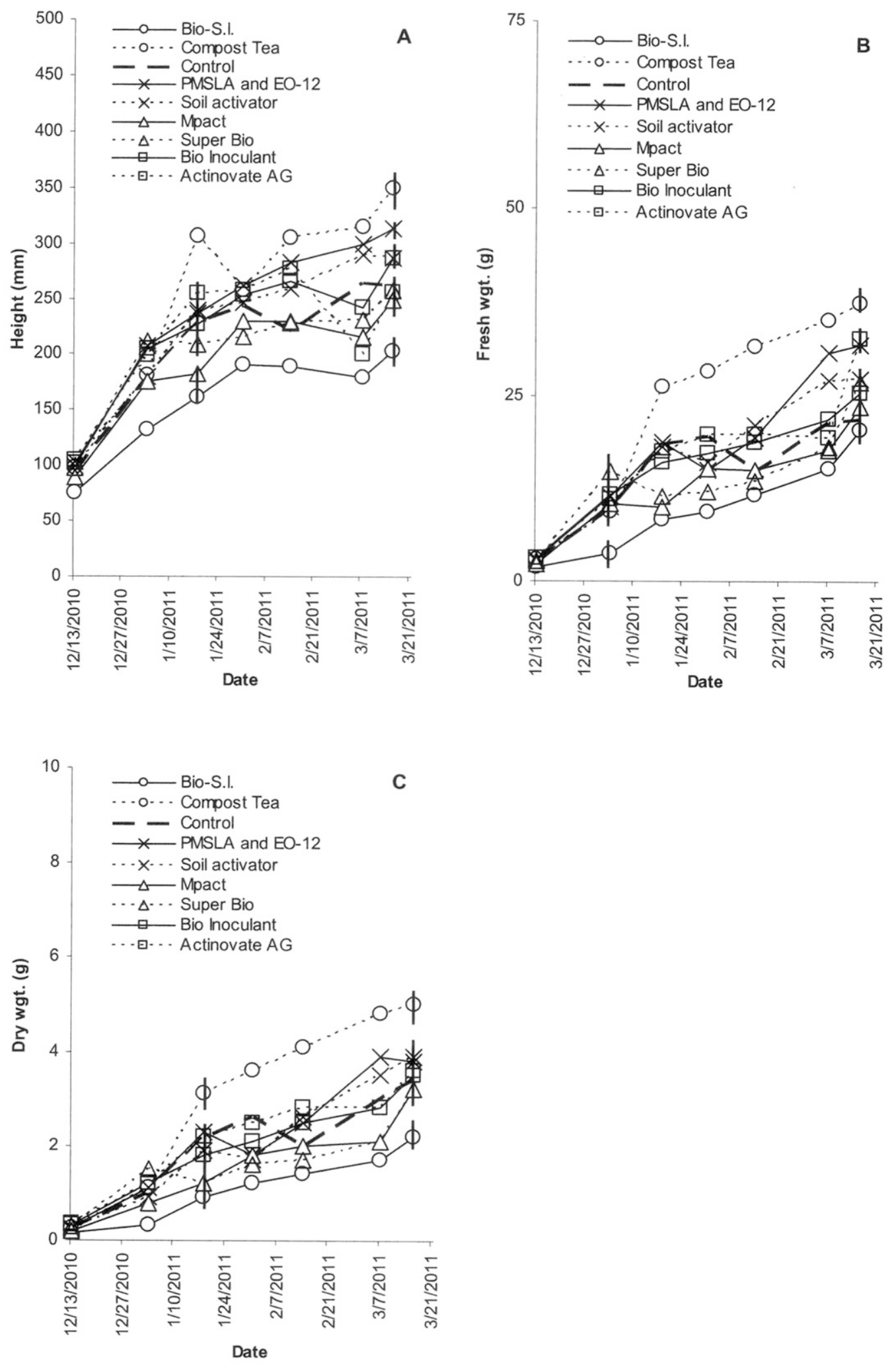

Fig. 2. Effects of amendment over sampling time on plant (A) height, $(\mathbf{B})$ fresh weight, and $(\mathbf{C})$ dry weight in bell pepper. sE bars are provided at apparent points of separation and/or at the final sampling date in Mar. 2011. The control is Nature's Harvest supplied weekly at $30 \mathrm{~mL} \cdot \mathrm{L}^{-1}$. 
sampling, fresh weights were greatest for plants treated with Compost Tea, Actinovate AG, PMSLA, and EO-12 (Fig. 2B). All other treatments were similar to controls. Plants treated with Compost Tea had the highest dry weights; all others were similar to controls except for plants treated with Bio-S.I., which had the least dry weights (Fig. 2C). Plants treated with Compost Tea produced more fruit than those treated with Bio-inoculant or Mpact; values for other treatments were similar to high and low values (Table 6). Plants treated with Compost Tea produced the heaviest fruit (Table 6).

Amendment, sampling date, and the interaction affected plant height and fresh weight of non-pungent jalapeños; only sampling date affected plant dry weight (Table 5). Fruit number (average 2.4/plant) and fresh weights (average $71.5 \mathrm{~g}$ ) were unaffected by amendment. Plant heights and fresh weights increased over time (Fig. 3A-B). At the last sampling, plants treated with Compost Tea, PMSLA and EO-12, Mpact, and Soil Activator were tallest (Fig. 3A). Bio-S.I., the control, Super Bio, and Bio Inoculant produced among the shortest plants; Actinovate AG was similar to both groups. Plants treated with Actinovate AG, Compost Tea, PMSLA and EO-12, Mpact, and Soil Activator produced the heaviest plants (Fig. 3B). All others were lighter and similar to the control. Plant dry weights increased from the first through last samplings (Table 7).

Chlorophyll, carotenoids, and vitamin C. Amendment did not affect concentration of these phytonutrients in fruit. Bell pepper average values were: $82.7 \mu \mathrm{g} \cdot \mathrm{g}^{-1}$ total chlorophyll; $57.4 \mu \mathrm{g} \cdot \mathrm{g}^{-1}$ chlorophyll $a$; $25.3 \mu \mathrm{g} \cdot \mathrm{g}^{-1}$ chlorophyll $b ; 2.2$ chlorophyll $a$ :chlorophyll $b$ ratio; $23.2 \mu \mathrm{g} \cdot \mathrm{g}^{-1}$ total carotenoids; 3.5 chlorophyll:carotenoid ratio; and $153.3 \mathrm{mg} / 100 \mathrm{~g}$ total vitamin C. For non-pungent jalapeños, average values were: $108.2 \mu \mathrm{g} \cdot \mathrm{g}^{-1}$ total chlorophyll; $75.2 \mu \mathrm{g} \cdot \mathrm{g}^{-1}$ chlorophyll $a$; $33.0 \mu \mathrm{g} \cdot \mathrm{g}^{-1}$ chlorophyll $b ; 2.3$ chlorophyll $a$ :chlorophyll $b$ ratio; $30.6 \mu \mathrm{g} \cdot \mathrm{g}^{-1}$ total carotenoids; 3.7 chlorophyll:carotenoid ratio; and $197.0 \mathrm{mg} / 100 \mathrm{~g}$ total vitamin $\mathrm{C}$.

Field. Peppers and cucumber results were not compared between years as a result of disparate environmental conditions. Sweet corn yield data were gathered for 2010. In 2011, sweet corn experienced crop failure; stalks were harvested and fresh weights determined. In each year, treatment did not affect responses. Cucumber averaged 61.7 and 35.26 Mt.ha ${ }^{-1}$ in 2010 and 2011, respectively. Bell pepper averaged 9.3 and $3.9 \mathrm{Mt} \cdot \mathrm{ha}^{-1}$ in 2010 and 2011, respectively. Non-pungent jalapeño peppers averaged 24.3 and 6.7 Mt.ha ${ }^{-1}$ in 2010 and 2011, respectively. Sweet corn averaged $54.1 \mathrm{Mt} \cdot \mathrm{ha}^{-1}$ in 2010 and stalks averaged $1.3 \mathrm{~kg} / \mathrm{stalk}$ in 2011 .

\section{Discussion}

In the greenhouse, nutrition in the medium was available to plants but over time would not sufficiently support normal growth. Nutrients in the irrigation water were constant across treatments and did not substantially add to plant nutrition. Application of fertil- izer allows plants to complete the life cycle. Amendments that have high microbial counts can be beneficial to plant growth (Paul and Metzger, 2005; Theunissen et al., 2010). Effects of amendment(s) in the presence of fertilizer, like under field conditions, can be gauged by comparison of cultivar responses to treatment.

Variation in plant weights at sampling dates reflects presence of immature fruit counted in plant weight; lower weights toward the end of sampling reflect weight of plant material only because mature fruit were removed. In addition, abscission of lower leaves and petioles would produce lower plant weight toward the end of the growing cycle. The application timing or amendment amount did not appear to affect results. Amendments that produced some of the best results in the greenhouse were applied most often with the smallest amount of product, i.e., Bio-S.I. on bell pepper, or applied once with the greatest amount of product, Compost Tea, in both peppers. Compost Teas can only be used if edible parts of plants are treated with the tea prepared so that it excludes certain materials and do not have, or have very low counts, of specific microbes (USDA, AMS, 2004).

Soils contain complex communities of microorganisms that, especially under conditions of organic/sustainable production, affect plant responses (Uphoff et al., 2006). Lack of response in the field may indicate that soils had well-developed, and balanced, microbial communities and may not benefit from additional or different microbes. The
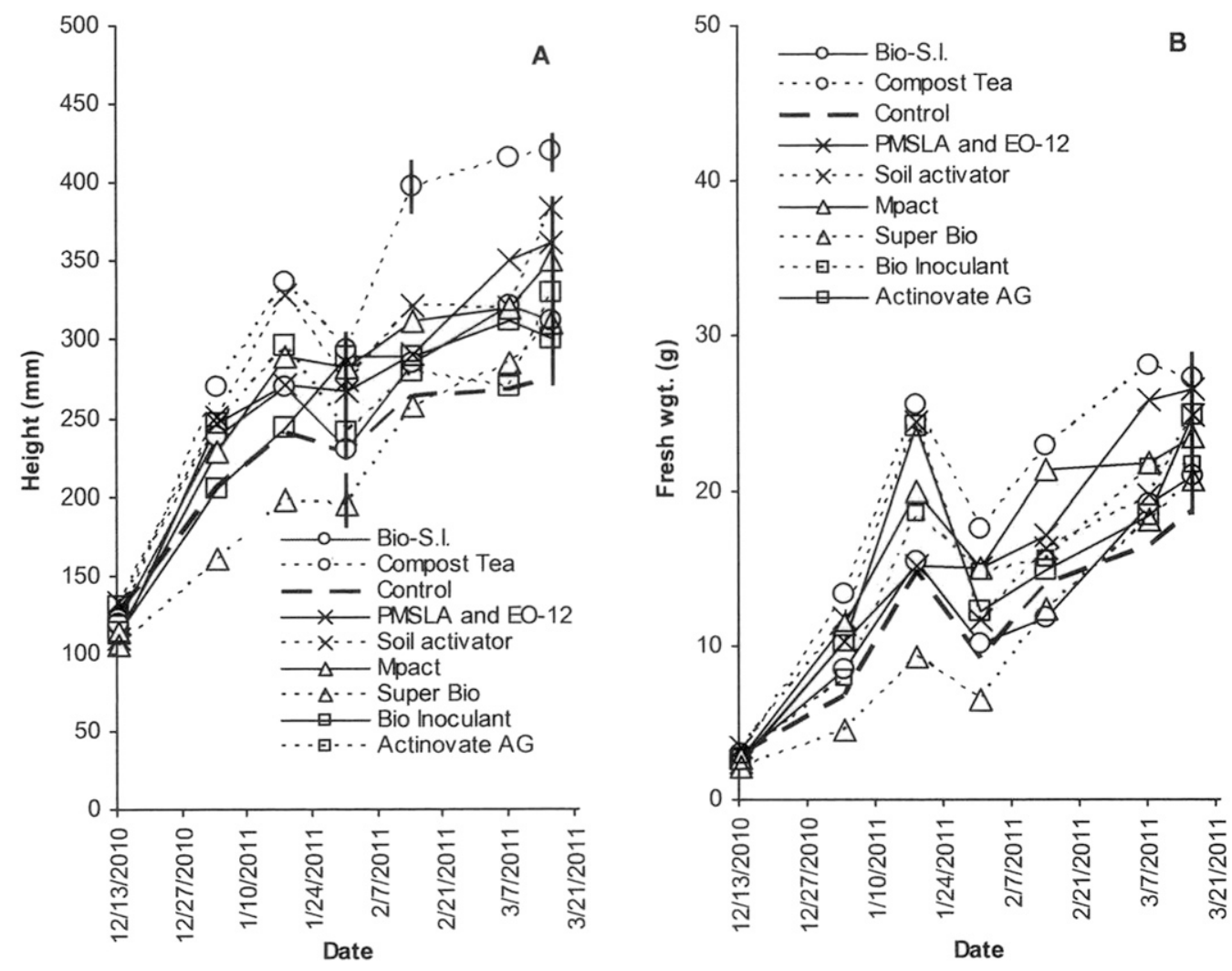

Fig. 3. Effects of amendment over sampling time on plant (A) height and (B) fresh weight in non-pungent Jalapeño pepper. SE bars are provided at apparent points of separation and/or at the final sampling date in Mar. 2011. The control is Nature's Harvest supplied weekly at $30 \mathrm{~mL} \cdot \mathrm{L}^{-1}$. 
amendments contain materials and/or microbes that could interact with the plants near, and possibly in, roots. Whether they should be expected to affect nutrient distribution in plants needs further examination. Use of microbial amendments does not guarantee a beneficial outcome (Broschat and Elliott, 2009). Russo and Perkins-Veazie (2010) placed pepper seed in media inoculated with mixes of bacteria or mycorrhizal fungi, different from what was used here. The plants that developed from seedlings transplanted to the field did not appear to receive any benefit to yield.

Microbes compete for nutrients (Thomashow and Weller, 1996) and presumably with plants as well. Microbes in amendments may compete with plants for nutrients or they may produce plant growth-limiting byproducts. The reason for detrimental effects resulting from some amendments needs further study. Tests under greenhouse or field conditions with the amendments indicated that there was no consistent benefit to their use. It is necessary that amendments be tested over various crops and production systems.

\section{Literature Cited}

Al-Rawahi, A.K. and J.G. Hancock. 1998. Parasitism and biological control of Verticillium dahliae by Pythium oligandrum. Plant Dis. 82:1100-1106.

Broschat, T.K. and M.L. Elliott. 2009. Effects of fertilization and microbial inoculants applied at transplanting on the growth of Mexican Fan Palm and Queen Palm. HortTechnology 19:324-330.

De Cal, A., R. Garcia-Lepe, and P. Melgarejo. 2000. Induced resistance by Penicillium oxalicum against Fusarium oxysporum f. sp. lycopersici: Histological studies of infected and induced tomato stems. Phytopathology 90:260-268.

Douds, D.D., Jr. and C. Reider. 2003. Inoculation with mycorrhizal fungi increases the yield of green peppers in a high $\mathrm{P}$ soil. Biol. Agric. Hortic. 21:91-102.

Glick, B.R. 2004. Changes in plant growth and development by rhizosphere bacteria that modify plant ethylene levels. Acta Hort. 631:265-273.

Gravel, V., C. Ménard, and M. Dorais. 2009. Pythium root rot and growth responses of organically grown Geranium plants to beneficial microorganisms. HortScience 44:1622-1627.

Hodges, D.M., W.V. Wismer, and C.F. Forney. 2001. Antioxidant responses in harvested leaves of two cultivars of spinach differing in senescence rates. J. Amer. Soc. Hort. Sci. 126:611-617.

Kokalis-Burelle, N., C.S. Vavrina, M.S. Reddy, and J.W. Klopper. 2003. Amendment of muskmelon and watermelon transplant media with plant growth-promoting rhizobacteria: Effects on seedling quality, disease, and nematode resistance. HortTechnology 13:476-482.

Lichtenhaler, H.K. and C. Buschmann. 2001. Extractions of photosynthetic tissues: Chlorophylls and carotenoids, p. F4.2.1-F42.6. In: Wrolstad, R.E., T.E. Acree, H. An, E.A. Decker, M.H. Penner, D.A. Reid, S.J. Schwartz, C.F. Shoemaker, and P. Sporns (eds.). Current protocols in food analytical chemistry. J.W. Wiley Sons, New York, NY.

Lucy, M., E. Reed, and B.R. Glick. 2004. Applications of free living plant growth-promoting rhizobacteria. Antonie van Leeuwenhoek 86:1-25.

Metcalf, D.A., J.J.C. Dennis, and C.R. Wilson. 2004. Effect of inoculum density of Sclerotium cepivorum on the ability of Trichoderma koningii to suppress white rot of onion. Plant Dis. 88:287-291.

Michaud, M., C. Martinez, A.-M. Simao-Beaunoir, R.R. Bélanger, and R.J. Tweddell. 2002. Selection of antagonist microorganisms against Helminthosporium solani, causal agent of Potato Silver Scurf. Plant Dis. 86:717-720.

Nemec, S., L.E. Datnoff, and J. Strandberg. 1996. Efficacy of biocontrol agents in planting mixes to colonize plant roots and control root diseases of vegetables and citrus. Crop Prot. 15:735742.

Paul, L.C. and J.D. Metzger. 2005. Impact of vermicompost on vegetable transplant quality. HortScience 40:2020-2023.

Prosser, J.I. 2006. Microorganisms cycling soil nutrients and their diversity, p. 237-261. In: van Elsas, J.D., J.K. Jansson, and J.T. Trevors (eds.). Modern soil microbiology, CRC Taylor \& Francis Press, Boca Raton, FL.

Russo, V.M. 2006. Biological amendment, fertilizer rate, and irrigation frequency for organic bell pepper transplant production. HortScience 41:1402-1407.

Russo, V.M. and P. Perkins-Veazie. 2010. Yield and nutrient content of bell pepper pods from plants developed from seedlings inoculated, or not, with microorganisms. HortScience 45:352358.

Schulze, J. and G. Pöschel. 2004. Bacterial inoculation of maize affects carbon allocation to roots and carbon turnover in the rhizosphere. Plant Soil 267:235-241.

Shimshick, E.J. and R.R. Herbert. 1979. Binding characteristics of N2-fixing bacteria to cereal roots. Appl. Environ. Microbiol. 38:447453.

Singh, R. and A. Adholeya. 2002. Plant and fungal responses to colonization, p. 213-230. In: Sharma, A.K. and B.N. Johri (eds.). Arbuscular mycorrhizae: Interactions in plants, rhizosphere, and soils. Science Publishers, Enfield, $\mathrm{NH}$.

Suresh, C.K. and D.J. Bagyaraj. 2002. Mycorrhizamicrobe interactions: Effect on rhizosphere, p. 7-28. In: Sharma, A.K. and B.N. Johri (eds.). Arbuscular mycorrhizae. Interactions in plants, rhizosphere, and soils. Science Publishers, Enfield, NH.

Sylvia, D., J. Fuhrmann, P. Hartzel, and D. Zuberer. 1997. Principles and applications of soil microbiology. Prentice Hall, Upper Saddle River, NJ.

Theunissen, J., P.A. Ndakidemi, and C.P. Laubscher. 2010. Potential of vermicompost produced from plant waste on the growth and nutrient status in vegetable production. International Journal of Physical Sciences 5:1964-1973.

Thies, J.E. and J.M. Grossman. 2006. The soil habitat and soil ecology, p. 59-78. In: Uphoff, N., A.S. Ball, E. Fernandes, H. Herren, O. Husson, M. Laing, C. Palm, J. Pretty, P. Sanchez, N. Sanginga, and J. Thies (eds.). Biological approaches to sustainable soil systems. CRC Taylor \& Francis Press, Boca Raton, FL.

Thomashow, L.S. and D.M. Weller. 1996. Current concepts in the use of introduced bacteria for biological control: Mechanisms and antifungal metabolites, p. 187-235. In: Stacey, G. and N.T. Keen (eds.). Plant-microbe interactions. Vol. 1. Chapman \& Hall, New York, NY.

United States Department of Agriculture/Agricultural Marketing Service. 2000. National Organic Program; final rule. 7 CFR Part 205. Fed. Regist. 21 Dec. 2000.

United States Department of Agriculture/Agricultural Marketing Service. 2004. National organic standards board. Compost tea task force final report. <http://www.ams.usda.gov/ nosb/ meetings/CompostTeaTaskForceFianl Repart. $\mathrm{pdf}>$.

Uphoff, N., A.S. Ball, E. Fernandes, H. Herren, O. Husson, M. Laing, C. Palm, J. Pretty, P. Sanchez, N. Sanginga, and J. Thies (eds.). 2006. Biological approaches to sustainable soil systems. CBC Taylor \& Francis, Boca Raton, FL.

Van Elsas, J.D., L. Tam, R.D. Finlay, K. Killham, and J.T. Trevors. 2006. Microbial interactions in soil, p. 177-210. In: van Elsas, J.D., J.K. Jansson and J.T. Trevors (eds.). Modern soil microbiology. CRC Taylor \& Francis Press, Boca Raton, FL.

Zahir, Z.A., M. Arshad, and W.T. Frankenberger. 2004. Plant growth promoting rhizobacteria: Applications and perspectives in agriculture. Adv. Agron. 81:97-168.

Zaki, K., I.J. Misaghi, A. Heydari, and M.N. Shatla. 1998. Control of cotton seedling damping-off in the field by Burkholderia (Pseudomonas) cepacia. Plant Dis. 82:291-293.

Zehnder, G.W., J.F. Murphy, E.J. Sikora, and W. Klopper. 2001. Application of rhizobacteria for induced resistance. Eur. J. Plant Pathol. 107: $39-50$. 